Article

\title{
Food Products as Sources of Protein and Amino Acids-The Case of Poland
}

\author{
Hanna Górska-Warsewicz *®D, Wacław Laskowski®, Olena Kulykovets®), \\ Anna Kudlińska-Chylak, Maksymilian Czeczotko and Krystyna Rejman
}

Department of Organization and Consumption Economics, Faculty of Human Nutrition and Consumer Sciences, Warsaw University of Life Sciences, 02-787 Warsaw, Poland; waclaw_laskowski@sggw.pl (W.L.); olena_kulykovets@sggw.pl (O.K.); anna_kudlinska_chylak@sggw.pl (A.K.-C.); maksymilian_czeczotko@sggw.pl (M.C.); krystyna_rejman@sggw.pl (K.R.)

* Correspondence: hanna_gorska_warsewicz@sggw.pl; Tel.: +48-22-59-37-144

Received: 9 October 2018; Accepted: 11 December 2018; Published: 13 December 2018

check for updates

\begin{abstract}
The aim of this study was to identify the food sources of protein and 18 amino acids (AAs) in the average Polish diet. The analysis was conducted based on the 2016 Household Budget Survey (HBS) on the consumption of food products from a representative sample of 38,886 households $(n=99,230)$. This survey was organized, conducted and controlled by the Central Statistical Office, Social Surveys and Living Conditions Statistics Department in cooperation with the Statistic Office in Łódź based on the recording of expenditures, quantitative consumption, and revenues in budget books for one month. 91 food products from 13 food categories (e.g., meat and meat products, grain products) consisting of 42 food groups (e.g., red meat, milk, cheese) were analyzed to determine protein and amino acid intake from these products. Three categories delivered $80.9 \%$ of total protein (meat and meat products: $38.9 \%$; grain products: $23.9 \%$; and milk and dairy products: $18.1 \%$ ). The branched-chain amino acids (BCAAs: leucine, isoleucine and valine) were delivered mainly by meat and meat products $(39.9 \% ; 41.3 \%$ and $37.4 \%$, respectively). Meat and meat products were also the most important source for other essential amino acids (EAAs: lysine $49.2 \%$, histidine $46.6 \%$, threonine $44.7 \%$, tryptophan $41.4 \%$, phenylalanine $35.3 \%$, and methionine $44.2 \%$ ). In terms of the contribution of the non-essential or conditionally essential amino acids to the average Polish diet, most important were grain products (for cysteine: $41.2 \%$; glutamic acid: $33.8 \%$; proline: $34.1 \%$ ), and meat and meat products (for tyrosine: $38.3 \%$; arginine: $46.1 \%$; alanine: $48.7 \%$; aspartic acid: $41.7 \%$; glycine: 52.5\%; serine: $33.6 \%$ ). Five clusters were identified to assess the impact of socio-demographic and economic factors on the protein supply. The largest impact was observed for respondent education, degree of urbanization, study month, and usage of agricultural land. The shares of animal food in total protein supply amounted to $66.5 \%$ in total population and varied from $56.4 \%$ to $73.6 \%$ in different clusters.
\end{abstract}

Keywords: protein; amino acids food sources; protein food sources

\section{Introduction}

Protein is a very important dietary macronutrient required for life [1-6] with various metabolic and physiologic functions, including the regulation of appetite, food intake, body weight, and body composition $[7,8]$. Its role in the regulation of blood pressure, glucose and lipid metabolism, bone metabolism, and the immune system [9,10] is also described in the scientific literature [9].

Taking into consideration the role of proteins and healthy eating patterns related to protein, it is important to analyze the consumption of food with respect to the share of particular food groups in the contribution of energy and nutrients. As far as protein and amino acids are concerned, type of 
protein to be eaten, protein quality and protein density should be analyzed [1]. The requirements for dietary protein are aimed at providing the minima for nine essential amino acids (EAAs) [11,12] or indispensable amino acids (IAAs) [13]. These are necessary for new protein structures and cannot be produced by the human body in physiologically significant amounts, and therefore must be supplied as crucial components of a balanced diet [11-13]. The EAAs include histidine, isoleucine, leucine, valine, lysine, threonine, phenylalanine, methionine, and tryptophan. Three of the nine EAAs (leucine, valine, and isoleucine) are the branched-chain amino acids (BCAAs) [12]. Some researchers have analyzed the role of BCAAs in muscle protein synthesis $[7,11,12,14-21]$. To the other amino acids belong 11 conditionally essential amino acids (CEAAs) and non-essential amino acids (NEAAs) [12,13].

There are a variety of proteins from a wide spectrum of food sources such as meat, milk, egg, soy, and other plants. Animal foods, in contrast to plant food, are perceived to have higher protein to energy ratios and better digestibility of protein and amino acids [6,7,9,22-25]. A US population study indicated that the share of animal food (including dairy products) in the total protein consumption amounted to $62 \%$ [26]. Fish, poultry, and red meat were the main sources of protein [7]. At the same time, meat and meat products contributed more to zinc, vitamin B12, phosphorus and iron intakes than plant food; however, plant products are higher contributors of fiber, vitamin E and magnesium [27]. Red meat-an important part of the human diet—provides high biological value protein and essential nutrients, some of which are more bioavailable than in alternative food sources [8]. Protein supply is a concern when the intake of both meat and dairy products is reduced [14]. At the same time, consuming a variety of protein food sources (meat, dairy products, fish, cereals, legumes) is advocated to ensure adequate nutrient intakes, as recommended by national guidelines [28].

These aspects are analyzed in economically developed countries [29] and in Western countries due to the development of various new dietary protein patterns in recent years, such as vegan, vegetarian and flexitarian diets [30]. The literature describes level of protein intake [26,31,32], dietary protein patterns in general and in relation to plant, animal and composite protein subgroups [33], and novel protein sources in terms of their possible protein delivery in the future [34].

The main aim of this study was to identify the food sources of protein and 18 amino acids in the average Polish diet, with special attention given to the rankings of food categories and groups in the contribution of protein and amino acids. It is the first attempt to estimate the sources of amino acids in the average Polish diet. Such information can be useful for dietary and health specialists to assess the quality of diets and to meet nutrient recommendations.

\section{Methods}

\subsection{Study Overview}

Only food sources of protein and 18 amino acids were analyzed. The 18 amino acids examined in this study were: histidine (His), leucine (Leu), isoleucine (Ile), lysine (Lys), valine (Val), threonine (Thr), tryptophan (Trp), phenylalanine (Phe), methionine (Met), cysteine (Cys), tyrosine (Tyr), arginine (Arg), alanine (Ala), aspartic acid (Asp), glutamic acid (Glu), glycine (Gly), proline (Pro) and serine (Ser).

\subsection{Sample Selection}

HBS is a representative method organized, conducted and controlled by the Central Statistical Office, Social Surveys and Living Conditions Statistics Department in cooperation with the Statistic Office in Łódź. The representative sample of the 2016 HBS consisted of 38,886 households $(n=99,230)$ which participated in the survey [35] by recording expenditures, quantitative consumption, and revenues in special budget books for one month. To select a representative sample, a two-stage, layered scheme was used. The sampling units of the first stage were area survey points and in the second one, flats and apartments were selected. The basis for the sampling frame for 1st degree units was the list of statistical regions developed for the needs of the National Census, updated each year with changes resulting from the administrative division of the country. The second-degree selection was made 
up of lists of inhabited flats and apartments in randomly selected area survey points, developed by statistical offices. In 2016, 911 area points were located in cities and 665 in rural areas [35,36]. Detailed information related to sample selection was presented in our previous paper [37]. The data on each household participating in the survey are from the "Budget Diary" and "Household's Statistical Sheet". Each household kept records of expenditures, quantitative food consumption and revenues for one month $[35,36]$.

In the 2016 HBS sample population, the share of women was $52.4 \%$. In the age structure, the largest share was represented by the following groups: $25-34$ years (12.6\%), 35-44 years (13.8\%), 45-54 years $(12.5 \%), 55-64$ years (15.8\%), 65 years and over (17.1\%). The share of people under 25 and children was $28.1 \%$ in total. The sample included four main types of households: employees $(N=17,877$ households, $n=55,799$ people), farmers $(N=1689, n=6481)$, self-employed $(N=2500, n=7970)$, retirees and pensioners $(N=13,323, n=25,195)$. The structure of households by the number of people was as follows: one-person $(N=7590, n=7590)$, two-person $(N=12,085, n=24,170)$, three-person $(N=7300$, $n=21,900)$, four-person $(N=6130, n=24,520)$, five-person $(N=2363, n=11,815)$, six and more-person $(N=1418, n=9235)$. In terms of educational level, the largest groups in the sample population were characterized by basic vocational $(27.4 \%)$, upper secondary vocational $(19.8 \%)$, higher (18.9\%), and primary (16.4\%) education [35].

Data on the consumption of food products were converted into one person per month using the information on the number of persons in the household and the number of days of using home nutrition. Such converted data on consumption should be regarded as a comprehensive diet [38].

\subsection{Food Grouping}

The HBS analyzed 91 food products. For the purposes of analysis of protein and amino acid contributions, there were 42 food and beverage groups in 13 food and beverage categories (Table 1). The food classification scheme was adapted from one published earlier [31,39-41]. The food classification included foods commonly consumed by Polish consumers [35].

Table 1. Food grouping for the purpose of the nutrient source analysis.

\begin{tabular}{|c|c|c|}
\hline Food Categories(13) & $\begin{array}{l}\text { Food Groups } \\
\qquad(42)\end{array}$ & $\begin{array}{l}\text { Food Products } \\
\text { (91) }\end{array}$ \\
\hline \multirow{5}{*}{ GRAIN PRODUCTS } & bread, rolls, bread products & $\begin{array}{l}\text { bread and rolls } \\
\text { quick breads and bread products }\end{array}$ \\
\hline & rice, cooked grains & $\begin{array}{l}\text { rice } \\
\text { groats and cereal grains }\end{array}$ \\
\hline & flour, bran, cooking ingredients & $\begin{array}{l}\text { wheat flour } \\
\text { other flours }\end{array}$ \\
\hline & pizza, pasta, and other flour dishes & $\begin{array}{c}\text { pasta, macaroni, noodle } \\
\text { pizza and other flour dishes }\end{array}$ \\
\hline & ready-to-eat cereal & breakfast cereals \\
\hline \multirow{4}{*}{ MEAT AND MEAT PRODUCTS } & red meat & $\begin{array}{c}\text { beef } \\
\text { pork } \\
\text { sheep, goat } \\
\text { veal }\end{array}$ \\
\hline & meat products & $\begin{array}{l}\text { processed red meat products } \\
\text { processed poultry meat products } \\
\text { other meat products }\end{array}$ \\
\hline & other meat & $\begin{array}{l}\text { liver and organ meat } \\
\text { minced meat } \\
\text { other meat }\end{array}$ \\
\hline & Poultry & $\begin{array}{c}\text { chicken } \\
\text { poultry excluding chicken }\end{array}$ \\
\hline
\end{tabular}


Table 1. Cont

\begin{tabular}{|c|c|c|}
\hline Food Categories(13) & $\begin{array}{c}\text { Food Groups } \\
(42)\end{array}$ & $\begin{array}{l}\text { Food Products } \\
\quad(91)\end{array}$ \\
\hline \multirow{4}{*}{ MILK AND DAIRY PRODUCTS } & Milk & $\begin{array}{c}\text { whole milk } \\
\text { reduced fat milk } \\
\text { condensed and powdered milk }\end{array}$ \\
\hline & Cheese & cheeses \\
\hline & cottage cheese & cottage cheese \\
\hline & yogurts and milk drinks & $\begin{array}{c}\text { yogurt, } \\
\text { milk shakes and other dairy drinks }\end{array}$ \\
\hline \multirow{3}{*}{ SEAFOOD } & Fish & fresh, chilled or frozen fish \\
\hline & Shellfish & fresh, chilled or frozen shellfish \\
\hline & processed seafood & $\begin{array}{l}\text { dried, smoked and salted seafood } \\
\text { other fish and shellfish products }\end{array}$ \\
\hline EGGS & Eggs & eggs \\
\hline \multirow{4}{*}{ FATS AND OILS } & Butter & butter \\
\hline & oils, olive & $\begin{array}{l}\text { olive oil } \\
\text { other oils }\end{array}$ \\
\hline & other fats & $\begin{array}{l}\text { margarine and other plant fats } \\
\text { other animal fats }\end{array}$ \\
\hline & sour cream & cream \\
\hline \multirow[t]{2}{*}{ FRUITS } & Fruits & $\begin{array}{c}\text { apples } \\
\text { bananas } \\
\text { berries } \\
\text { citrus fruits } \\
\text { frozen fruits } \\
\text { fruits products } \\
\text { other fruits } \\
\text { peaches and nectarines }\end{array}$ \\
\hline & dried fruits and nuts & dried fruits and nuts \\
\hline \multirow[b]{2}{*}{ VEGETABLES } & Potatoes & $\begin{array}{c}\text { potatoes } \\
\text { potatoes products }\end{array}$ \\
\hline & vegetables (excluding potatoes) & $\begin{array}{c}\text { beetroot } \\
\text { cabbage } \\
\text { carrots } \\
\text { cauliflower } \\
\text { cucumber } \\
\text { lettuce } \\
\text { onions } \\
\text { tomatoes } \\
\text { frozen vegetables and mushrooms } \\
\text { sour cabbage } \\
\text { other vegetables and mushrooms } \\
\text { vegetable and mushrooms } \\
\text { products }\end{array}$ \\
\hline \multirow{4}{*}{ SNACKS AND SWEETS } & Chocolate & $\begin{array}{c}\text { chocolate } \\
\text { powdered cacao } \\
\text { powdered chocolate }\end{array}$ \\
\hline & Desserts & ice-cream \\
\hline & Snacks & chips \\
\hline & sweet bakery products & cakes and pies \\
\hline
\end{tabular}


Table 1. Cont.

\begin{tabular}{|c|c|c|}
\hline Food Categories(13) & $\begin{array}{c}\text { Food Groups } \\
(42)\end{array}$ & $\begin{array}{l}\text { Food Products } \\
\quad(91)\end{array}$ \\
\hline \multirow{5}{*}{ SUGARSAND SALT } & Honey & honey \\
\hline & jams, syrups, marmalade & $\begin{array}{l}\text { jams } \\
\text { syrups } \\
\text { marmalade }\end{array}$ \\
\hline & Sugar & sugar \\
\hline & sugar substitutes & sugar substitutes \\
\hline & Salt & salt \\
\hline \multirow{3}{*}{ BEVERAGES, NONALCOHOLIC } & Juices & $\begin{array}{c}\text { fruit juices } \\
\text { vegetables and mixed juices }\end{array}$ \\
\hline & other beverages & other nonalcoholic beverages \\
\hline & Water & water \\
\hline \multirow{2}{*}{ COFFEE, TEA } & Coffee & coffee \\
\hline & Tea & tea \\
\hline \multirow{3}{*}{ ALCOHOLIC BEVERAGES } & Wine & $\begin{array}{c}\text { grape wine } \\
\text { high alcohol wine } \\
\text { other wine } \\
\text { wine-based beverages }\end{array}$ \\
\hline & Beer & $\begin{array}{c}\text { beer lager } \\
\text { low-alcohol and non-alcohol beer } \\
\text { other beer } \\
\text { beer-based beverages }\end{array}$ \\
\hline & other alcoholic beverages & $\begin{array}{l}\text { liquor and cocktails } \\
\text { other alcoholic beverages }\end{array}$ \\
\hline
\end{tabular}

\subsection{Statistical Analysis and Data Presentation}

To calculate the protein and amino acid content of the food, the 'Nutritive Value Tables for Foods and Meals' (4th ed., 2017) [42] were used. This edition was developed and updated by the Food and Nutrition Institute with special attention given to new products and technological modifications taking place in the Polish food industry. In comparison to the previous edition (3rd ed., 2005), the content of fatty acids and amino acids was taken into account; therefore, calculations required for the purposes of this study were possible. From the base of 1100 products and assortment items, 930 products were selected. The weights of the known or estimated proportions of the consumption of given products relative to others in the group were applied, if necessary, to calculate the average protein and amino acids contents. This database was inputted into the $\mathrm{R}$ program ( $\mathrm{v}$ 3.0.2), a system and environment for statistical computation [43-45], and used to calculate values and contents of protein and amino acids in food consumed in each of the 38,886 households $(n=99,230)$. A weight of corrections was used to analyze the diversity of household structure and to improve the representativeness of the results $[38,46-48]$. Means and standard errors of energy were calculated for 13 food and beverage categories and 42 food and beverage groups. Means of the protein and amino acid intakes were expressed as percentages of the total dietary intake of the analyzed nutrient. Percentages of protein and amino acids supply of food categories and groups are presented in rank order.

To assess the impact of socio-demographic and economic factors on the protein supply in the average Polish diet, exploratory data analysis (EDA) was applied. In the literature, the EDA is described as a method or approach to gaining new insights into data, identifying important factors in the data and understanding relationships $[47,49,50]$. We used a cluster analysis as an exploratory tool to sort data into groups, which is widely discussed in the scientific literature [51-59]. In our calculations, eight food categories of protein sources were considered, which statistically account for 
the delivery of $98.7 \%$ of the total protein. Based on a multidimensional exploratory analysis of the percentage share of protein from theses eight sources, five clusters (groups) were identified. For this purpose, the Neural Networks module available in the Statistica 13.3 program was used and Kohonen Neural Network was selected from the list of available networks [60]. The division into five clusters is characterized by an averaged correlation measure (correlation ratio) of almost 0.5.

The description of clusters includes the following socio-demographic and economic features: respondent education, degree of urbanization, study month, usage of agricultural land, socio-economic type of household (i.e., households of employees, farmers, self-employed, living on unearned sources, and retirees and pensioners), size of the village, family life phase, age, income measured according to the quintiles group, province, assessment of the household's financial situation, number of people in the household, region and sex. For each such feature, and considering the exploratory classification obtained, a correlation table was created together with a chi2 test and a measure of Cramer's correlation. The most important data related to the share of main food categories in terms of the contribution of protein and 18 amino acids are presented in Section 3 "Results".

Detailed data related to the share of 13 food and beverage categories and 42 food and beverage groups in terms of the contribution of total protein and all analyzed AAs are shown in the Supplemental Section.

\section{Results}

Sources of protein and 18 amino acids from the main food and beverage categories are shown in Tables 2-6, which appear in this article, and detailed data are presented in Tables S1-S19 in the Supplemental Section.

\subsection{Protein Sources}

Sources of protein calculated for food categories are shown in Table 2, and for food groups in Table S1 (Supplemental Section). The three highest sources of protein were meat and meat products $(39.0 \%)$, grain products $(23.9 \%)$, and milk and dairy products $(18.1 \%)$ (Table 2$)$. The highest ranked food group sources of protein were meat products $(17.4 \%)$, bread, rolls, bread products $(16.5 \%)$, red meat $(9.9 \%)$, poultry $(9.7 \%)$, and cheese $(5.6 \%)$ (Table S1).

Table 2. Food category sources of protein contribution to the average Polish diet.

\begin{tabular}{cccc}
\hline Food Categories & Rank & \% of Protein Contribution & Cumulative \% of Protein Contribution \\
\hline meat and meat products & 1 & 39.0 & 39.0 \\
grain products & 2 & 23.9 & 62.9 \\
milk and dairy products & 3 & 18.1 & 81.0 \\
vegetables & 4 & 7.9 & 88.9 \\
eggs & 5 & 3.5 & 92.4 \\
seafood & 6 & 2.6 & 95,0 \\
snacks and sweets & 7 & 2.4 & 97.4 \\
fruits & 8 & 1.3 & 98.7 \\
fats and oils & 9 & 0.6 & 99.3 \\
nonalcoholic beverages & 10 & 0.4 & 99.7 \\
alcoholic beverages & 11 & 0.3 & 100.0 \\
\hline
\end{tabular}

\subsection{Food Sources of BCAAs}

The main food sources of BCAAs calculated in food categories are shown in Table 3. The detailed data related to food categories and groups are presented in Supplemental Tables S2-S4.

The main food categories that are contributors to leucine consumption were meat and meat products $(39.9 \%)$, grain products $(22.1 \%)$, and milk and dairy products $(20.0 \%)$ (Table 3$)$. When considering food groups, the main sources of leucine were processed red meat products $(18.4 \%)$, bread, rolls and bread products (14.9\%), red meat (10.5\%), poultry $(9.0 \%)$, and milk (6.2\%) (Table S2).

Meat and meat products contributed $41.3 \%$ of isoleucine in the average Polish diet. The other sources of isoleucine were grain products (21.3\%), and milk and dairy products (19.1\%) (Table 3). 
When considering food groups, the main sources of isoleucine were processed meat products (19.2\%), bread, rolls and bread products (14.8\%), red meat (10.3\%), poultry $(10.1 \%)$, and pork (6.3\%) (Table S3).

The top contributors of valine were: meat and meat products, grain products, and milk and dairy products, delivering $80.3 \%$ of total valine supply (Table 3) and as detailed food groups: meat products $(16.6 \%)$, bread, rolls and bread products $(15.3 \%)$, poultry $(9.5 \%)$, red meat $(9.5 \%)$, and milk $(6.5 \%)$ (Table S4).

Table 3. Main food category sources of leucine, isoleucine and valine contribution to the average Polish diet.

\begin{tabular}{|c|c|c|c|}
\hline Food Categories & Rank & $\%$ of Contribution & Cumulative \% of Contribution \\
\hline \multicolumn{4}{|l|}{ Leucine } \\
\hline meat and meat products & 1 & 39.9 & 39.9 \\
\hline grain products & 2 & 22.1 & 62.0 \\
\hline milk and dairy products & 3 & 20.0 & 82.0 \\
\hline vegetables & 4 & 7.0 & 89.0 \\
\hline eggs & 5 & 3.9 & 92.9 \\
\hline \multicolumn{4}{|l|}{ Isoleucine } \\
\hline meat and meat products & 1 & 41.3 & 41.3 \\
\hline grain products & 2 & 21.3 & 62.6 \\
\hline milk and dairy products & 3 & 19.1 & 81.7 \\
\hline vegetables & 4 & 6.9 & 88.6 \\
\hline eggs & 5 & 4.3 & 92.9 \\
\hline \multicolumn{4}{|l|}{ Valine } \\
\hline meat and meat products & 1 & 37.4 & 37.4 \\
\hline grain products & 2 & 22.1 & 59.5 \\
\hline milk and dairy products & 3 & 20.8 & 80.3 \\
\hline vegetables & 4 & 7.8 & 88.1 \\
\hline eggs & 5 & 4.3 & 92.4 \\
\hline
\end{tabular}

\subsection{Food Sources of Other EAAs}

The main food sources of other EAAs (lysine, histidine, threonine, tryptophan, phenylalanine, and methionine) from food categories are shown in Table 4. Detailed data related to all food categories and groups are presented in Supplemental Tables S5-S10.

Meats and meat products are a very important source of lysine, delivering almost half of total intake (Table 4). The two other main food categories which were contributors of lysine were milk and dairy products $(21.5 \%)$, and grain products $(11.0 \%)$. The highest ranked food group sources of lysine were meat products $(22.3 \%)$, poultry $(12.4 \%)$, red meat $(12.3 \%)$, bread, rolls and bread products $(7.5 \%)$, and milk (7.4\%) (Table S5).

Meat and meat products were the sources for c.a. $46.5 \%$ of histidine in the average Polish diet (Table 4$)$. The other two largest sources of histidine were grain products $(19.2 \%)$, and milk and dairy products $(17.0 \%)$. The highest-ranked food group sources of histidine were processed meat products $(21.2 \%)$, bread, rolls and bread products $(13.1 \%)$, red meat $(11.8 \%)$, poultry $(11.6 \%)$, and cheese $(5.8 \%)$ (Table S6).

Meats and meat products were the source of nearly $45 \%$ of threonine in the average Polish diet (Table 4). The other largest sources of threonine were grain products (18.5\%), and milk and dairy products $(17.6 \%)$. When considering food groups, the main sources of threonine were meat products $(20.6 \%)$, bread, rolls and bread products $(12.7 \%)$, red meat $(12.3 \%)$, poultry $(9.8 \%)$ and vegetables excluding potatoes $(5.3 \%)$ (Table S7).

The level of tryptophan derived from food is presented in Table 4 and Table S8. The main food category contributors of tryptophan in the average Polish diet were meat and meat products (41.4\%), grain products (19.2\%), and milk and dairy products (18.9\%) (Table 4). When considering food groups, 
the top five ranked foods were meat products $(18.4 \%)$, bread, rolls and bread products $(12.9 \%)$, red meat $(10.6 \%)$, poultry $(10.6 \%)$, and cheese $(6.2 \%)$ (Table S8).

Meats and meat products were the sources for c.a. $35 \%$ of phenylalanine in the average Polish diet (Table 4). Phenylalanine was also delivered by grain products and milk and dairy products. Detailed data on food sources of phenylalanine are presented in Table S9 with main rank positions related to: bread, rolls and bread products $(18.0 \%)$, meat products $(16.4 \%)$, red meat $(9.2 \%)$, poultry $(7.9 \%)$, and cheese $(6.2 \%)$.

Meats and meat products contributed $44.2 \%$ of methionine (Table 4 ) in the average Polish diet. The next two main food categories-grain products and milk and dairy products-contributed nearly $39 \%$ of methionine. Detailed data showed the highest ranked food sources of methionine to be meat products $(19.9 \%)$, bread, rolls and bread products $(13.7 \%)$, poultry $(11.4 \%)$, red meat $(11.1 \%)$, and cheese (5.6\%) (Table S10).

Table 4. Main food category sources of the contribution of lysine, histidine, threonine, tryptophan, phenylalanine, and methionine to the average Polish diet.

\begin{tabular}{|c|c|c|c|}
\hline Food Categories & Rank & $\%$ of Contribution & Cumulative $\%$ of Contribution \\
\hline \multicolumn{4}{|l|}{ Lysine } \\
\hline meat and meat products & 1 & 49.2 & 49.2 \\
\hline milk and dairy products & 2 & 21.5 & 70.7 \\
\hline grain products & 3 & 11.0 & 81.7 \\
\hline vegetables & 4 & 7.5 & 89.2 \\
\hline Eggs & 5 & 3.3 & 92.5 \\
\hline \multicolumn{4}{|l|}{ Histidine } \\
\hline meat and meat products & 1 & 46.6 & 46.6 \\
\hline grain products & 2 & 19.2 & 65.8 \\
\hline milk and dairy products & 3 & 17.0 & 82.8 \\
\hline vegetables & 4 & 6.5 & 89.3 \\
\hline seafood & 5 & 3.2 & 92.5 \\
\hline \multicolumn{4}{|l|}{ Threonine } \\
\hline meat and meat products & 1 & 44.7 & 44.7 \\
\hline grain products & 2 & 18.5 & 63.2 \\
\hline milk and dairy products & 3 & 17.5 & 80.7 \\
\hline vegetables & 4 & 7.8 & 88.5 \\
\hline eggs & 5 & 4.0 & 92.5 \\
\hline \multicolumn{4}{|l|}{ Tryptophan } \\
\hline meat and meat products & 1 & 41.4 & 41.3 \\
\hline grain products & 2 & 19.2 & 60.6 \\
\hline milk and dairy products & 3 & 18.9 & 79.5 \\
\hline vegetables & 4 & 9.0 & 88.5 \\
\hline eggs & 5 & 4.2 & 92.7 \\
\hline \multicolumn{4}{|l|}{ Phenylalanine } \\
\hline meat and meat products & 1 & 35.3 & 35.3 \\
\hline grain products & 2 & 26.3 & 61.6 \\
\hline milk and dairy products & 3 & 19.2 & 80.8 \\
\hline vegetables & 4 & 7.9 & 88.7 \\
\hline eggs & 5 & 4.4 & 93.1 \\
\hline \multicolumn{4}{|l|}{ Methionine } \\
\hline meat and meat products & 1 & 44.2 & 44.2 \\
\hline grain products & 2 & 20.0 & 64.2 \\
\hline milk and dairy products & 3 & 18.4 & 82.6 \\
\hline vegetables & 4 & 5.1 & 87.7 \\
\hline eggs & 5 & 4.9 & 92.6 \\
\hline
\end{tabular}




\subsection{Food Sources of CEAAs}

The main food sources of CEAAs calculated in food categories are shown in Table 5. Detailed data related to all food categories and food groups are presented in Supplemental Tables S11-S15.

Grain products are very important sources of cysteine, delivering $41.7 \%$ of total intake (Table 5). The other main food category as a contributor to cysteine was meat and meat products (31.4\%). The highest-ranked food group sources of cysteine were bread, rolls and bread products (29.0\%), meat products $(14.6 \%)$, red meat $(8.1 \%)$, poultry $(7.1 \%)$, and flour, bran and cooking ingredients $(6.3 \%)$ (Table S11).

The three highest sources of tyrosine were meat and meat products $(38.3 \%)$, milk and dairy products $(23.6 \%)$, and grain products $(20.6 \%)$ (Table 5). When considering food groups, the main sources of tyrosine were meat products $(17.7 \%)$, bread, rolls and bread products $(14.5 \%)$, red meat $(10.0 \%)$, poultry $(8.8 \%)$, and cheese $(8.3 \%)$ (Table S12).

Meat and meat products were the sources for c.a. $46.1 \%$ of arginine in the average Polish diet (Table 5). The other largest sources of arginine were meat products (21.0\%), and poultry (11.3\%). When considering food groups, the main sources of arginine were meat products $(20.9 \%)$, bread, rolls and bread products $(14.3 \%)$, red meat $(12.1 \%)$, poultry $(10.9 \%)$, and vegetables excluding potatoes $(7.2 \%)$ (Table S13).

Meat and meat products are very important sources of glycine, delivering about half of the total intake (Table 5). The two other main food categories that were contributors of glycine were grain products $(21.05 \%)$ and milk and dairy products $(7.84 \%)$. The highest-ranked food group sources of glycine were meat products $(21.0 \%)$, poultry $(15.4 \%)$, bread, rolls and bread products $(14.4 \%)$, red meat $(12.8 \%)$, and vegetables excluding potatoes (5.4\%) (Table S14).

For proline, the grain products were the main contributors, delivering $34.1 \%$ of total supply (Table 5). The next positions were occupied by meat and meat products $(26.7 \%)$ and milk and dairy products $(24.8 \%)$. When detailed data are taken into consideration, the share of four food groups (bread, rolls, and bread rolls; meat products; cheese; and poultry) exceeded 50\% of the total supply (Table S15).

Table 5. Main food category sources of the contribution of cysteine, tyrosine, arginine, proline, and glycine to the average Polish diet.

\begin{tabular}{cccc}
\hline Food Categories & Rank & \% of Contribution & Cumulative \% of Contribution \\
\hline Cysteine & \multicolumn{3}{c}{} \\
\hline grain products & 1 & 41.7 & 41.7 \\
meat and meat products & 2 & 31.4 & 73.1 \\
milk and dairy products & 3 & 8.5 & 81.6 \\
vegetables & 4 & 6.4 & 88.0 \\
eggs & 5 & 5.1 & 93.1 \\
\hline Tyrosine & & & \\
\hline meat and meat products & 1 & 38.3 & 38.3 \\
milk and dairy products & 2 & 23.6 & 61.9 \\
grain products & 3 & 20.6 & 82.5 \\
vegetables & 4 & 6.3 & 92.8 \\
eggs & 5 & 4.0 & \\
\hline Arginine & & & 66.1 \\
\hline meat and meat products & 1 & 46.1 & 78.4 \\
grain products & 2 & 21.0 & 88.0 \\
milk and dairy products & 3 & 11.3 & 92.1 \\
vegetables & 4 & 9.6 & \\
eggs & 5 & 4.1 & \\
\hline
\end{tabular}


Table 5. Cont.

\begin{tabular}{cccc}
\hline Food Categories & Rank & \% of Contribution & Cumulative \% of Contribution \\
\hline Glycine & & & \\
\hline meat and meat products & 1 & 52.5 & 52.5 \\
grain products & 2 & 21.0 & 73.5 \\
milk and dairy products & 3 & 7.8 & 81.4 \\
vegetables & 4 & 7.5 & 88.9 \\
seafood & 5 & 3.4 & 92.3 \\
\hline Proline & & & \\
grain products & 1 & 34.1 & 34.1 \\
meat and meat products & 2 & 26.7 & 80.8 \\
milk and dairy products & 3 & 24.8 & 91.6 \\
vegetables & 4 & 5.4 & 93.4 \\
snacks and sweets & 5 & 2.4 & \\
\hline
\end{tabular}

\subsection{Food Sources of NEAAs}

The main food sources of NEAAs calculated in food categories are shown in Table 6. The detailed data related to food categories and food groups are presented in Supplemental Tables S16-S19.

Aspartic acid was delivered to the average Polish diet by the following food categories: meat and meat products $(41.7 \%)$, grain products $(16.7 \%)$, and milk and dairy products $(14.3 \%)$ (Table 6$)$ and detailed food groups: meat products $(18.5 \%)$, bread, rolls and bread products $(11.4 \%)$, poultry $(10.7 \%)$, red meat $(10.5 \%)$ and vegetables without potatoes $(7.1 \%)$ (Table S16).

The main contributors of glutamic acid to the average Polish diet were grain products delivering c.a. 1/3 of total supply (Table 6). The other important food categories in glutamic acid included meat and meat products (30.9\%) and milk and dairy products (19.0\%). In food group specifications, the highest ranks were obtained by: bread, rolls and bread products $(23.2 \%)$, meat products $(14.0 \%)$, red meat $(7.8 \%)$, poultry $(7.7 \%)$ and cheese $(6.2 \%)$ (Table S17).

Meat and meat products delivered $33.6 \%$ of serine (Table 6). The other main food categories contributing serine were: grain products $(24.0 \%)$, and milk and dairy products $(21.1 \%)$. The detailed specification of serine contribution indicated the following food groups: bread, rolls and bread products $(16.9 \%)$, meat products $(15.1 \%)$, red meat $(8.4 \%)$, poultry $(8.3 \%)$, and cheese $(6.5 \%)$ (Table S18).

The top contributors of alanine were the following main food categories: meat and meat products $(48.7 \%)$, grain products $(19.2 \%)$, and milk and dairy products (11.9\%) (Table 5) and food groups: meat products $(21.2 \%)$, bread, rolls and bread products $(13.1 \%)$, poultry $(12.9 \%)$, red meat $(12.1 \%)$, and vegetables excluding potatoes (5.6\%) (Table S19).

\subsection{Summary of AAs Sources}

Meat and meat products, grain products, and milk and dairy products reviewed jointly were important sources of amino acids delivering more than $80 \%$ of proline, glutamic acid, tyrosine, histidine, methionine, cysteine, lysine, glycine, leucine, isoleucine, phenylalanine, threonine, and valine (Table 7). In the case of glycine, lysine, alanine, histidine, arginine, threonine, methionine, aspartic acid, tryptophan and isoleucine, meat and meat products were responsible for more than $40 \%$ of daily intake. Grain products delivered more than $30 \%$ of the average daily intake in the case of cysteine, glutamic acid, and proline. An important contribution (more than $20 \%$ of daily intake) of milk and dairy products to the daily consumption of proline, tyrosine, serine, valine, lysine, and leucine was observed. 
Table 6. Main food category sources of the contribution of aspartic acid, glutamic acid, serine, and alanine to the average Polish diet.

\begin{tabular}{|c|c|c|c|}
\hline Food Categories & Rank & $\%$ of Contribution & Cumulative $\%$ of Contribution \\
\hline \multicolumn{4}{|l|}{ Aspartic Acid } \\
\hline meat and meat products & 1 & 41.7 & 41.7 \\
\hline grain products & 2 & 16.7 & 58.4 \\
\hline milk and dairy products & 3 & 14.3 & 72.7 \\
\hline vegetables & 4 & 13.8 & 86.5 \\
\hline eggs & 5 & 3.5 & 90.0 \\
\hline \multicolumn{4}{|l|}{ Glutamic Acid } \\
\hline grain products & 1 & 33.8 & 33.8 \\
\hline meat and meat products & 2 & 30.9 & 64.7 \\
\hline milk and dairy products & 3 & 10.0 & 83.7 \\
\hline vegetables & 4 & 7.2 & 90.9 \\
\hline eggs & 5 & 2.4 & 93.3 \\
\hline \multicolumn{4}{|l|}{ Serine } \\
\hline meat and meat products & 1 & 33.6 & 33.6 \\
\hline grain products & 2 & 24.0 & 57.6 \\
\hline milk and dairy products & 3 & 21.1 & 78.7 \\
\hline vegetables & 4 & 7.7 & 86.4 \\
\hline eggs & 5 & 5.6 & 92.0 \\
\hline \multicolumn{4}{|l|}{ Alanine } \\
\hline meat and meat products & 1 & 48.7 & 48.7 \\
\hline grain products & 2 & 19.2 & 67.8 \\
\hline milk and dairy products & 3 & 11.9 & 79.7 \\
\hline vegetables & 4 & 7.8 & 87.5 \\
\hline eggs & 5 & 4.3 & 91.8 \\
\hline
\end{tabular}


Table 7. The shares (in \%) of three main food categories in the contribution of amino acids to the average Polish diet.

\begin{tabular}{|c|c|c|c|c|c|}
\hline \multirow{2}{*}{$\begin{array}{l}\begin{array}{c}\text { Amino } \\
\text { Acids }\end{array} \\
\text { glycine }\end{array}$} & \multirow{2}{*}{$\begin{array}{c}\text { Total Share of } 3 \text { Food } \\
\text { Categories }\end{array}$} & $\begin{array}{l}\text { Meat and Meat Products } \\
\text { (share in \%) }\end{array}$ & $\begin{array}{l}\text { Grain Products } \\
\text { (share in \%) }\end{array}$ & \multicolumn{2}{|c|}{$\begin{array}{c}\text { Milk and Dairy Products } \\
\text { (share in \%) }\end{array}$} \\
\hline & & 52.5 & 21.1 & 7.8 & 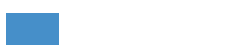 \\
\hline lysine & 81.7 & 49.2 & 11.0 & 21.5 & \\
\hline alanine & 79.7 & 48.7 & 19.2 & 11.9 & \\
\hline histidine & 82.8 & 46.6 & 19.2 & 17.0 & \\
\hline arginine & 78.4 & 46.1 & 21.0 & 11.3 & \\
\hline threonine & 80.7 & 44.7 & 18.5 & 17.5 & \\
\hline methionine & 82.6 & 44.2 & 20.0 & 18.4 & \\
\hline aspartic acid & 72.7 & 41.7 & 16.7 & 14.3 & \\
\hline tryptophan & 79.5 & 41.4 & 19.2 & 18.9 & \\
\hline isoleucine & 81.7 & 41.3 & 21.3 & 19.1 & \\
\hline leucine & 82.0 & 39.9 & 22.1 & 20.0 & \\
\hline tyrosine & 82.5 & 38.3 & 20.6 & 23.6 & \\
\hline valine & 80.3 & 37.4 & 22.1 & 20.8 & \\
\hline phenylalanine & 80.8 & 35.3 & 26.3 & 19.2 & \\
\hline serine & 78.7 & 33.6 & 24.0 & 21.1 & \\
\hline cysteine & 81.6 & 31.4 & 41.7 & 8.5 & \\
\hline glutamic acid & 83.7 & 30.9 & 33.8 & 19.0 & \\
\hline proline & 85.6 & 26.7 & 34.1 & 24.8 & \\
\hline
\end{tabular}




\subsection{Cluster Analysis Based on Protein Sources}

To assess the impact of socio-demographic and economic factors on the protein supply in the average Polish diet, eight categories of protein sources as classification features were considered (Table 8). Five clusters were identified, which ensured the highest value of correlation ratio (0.48). The largest impact on the total protein intake in clusters was observed for the following factors: respondent education, degree of urbanization, study month, and usage of agricultural land (Table 9). In individual clusters, a different value of animal vs. plant protein ratio and various shares of eight food categories in total protein intake were observed. The shares of animal food in total protein supply amounted to $66.5 \%$ in total population and varied from $56.4 \%$ in cluster 2 to $73.6 \%$ in cluster 4 . In comparison, plant food was the source of less protein (33.5\% in total population, $26.4 \%$ in cluster 4 , and $43.6 \%$ in cluster 2), (Table 10). Considering the eight categories as protein sources, the largest differences among clusters were found for meat and its products, which were greater than those for cereal products, and milk and dairy products. However, it is worth noting that one cluster differed from the others primarily by the percentage of seafood protein (Figure 1).

Table 8. Description of cluster analysis: protein sources as classification features.

\begin{tabular}{cc}
\hline Food Category & Correlation Ratio \\
\hline meat and meat products & 0.84 \\
grain products & 0.72 \\
milk and dairy products & 0.74 \\
vegetables & 0.22 \\
eggs & 0.2 \\
seafood & 0.67 \\
snacks and sweets & 0.23 \\
fruits & 0.26 \\
average & 0.48 \\
\hline
\end{tabular}

Table 9. Dependence of cluster analysis on socio-demographic and economic factors.

\begin{tabular}{cc}
\hline Factors & Cramer Correlation \\
\hline education & 0.158 \\
degree of urbanization & 0.138 \\
study month & 0.135 \\
usage of agricultural land & 0.133 \\
socio-economic type of household & 0.118 \\
size of the village & 0.114 \\
family life phase & 0.105 \\
age & 0.101 \\
income (quintile group) & 0.100 \\
province & 0.099 \\
assessment of financial situation & 0.080 \\
number of people in household & 0.066 \\
region & 0.057 \\
sex & 0.033 \\
\hline
\end{tabular}

Table 10. Cluster description: animal vs. plant food.

\begin{tabular}{ccccccc}
\hline & Sample Population & Cluster 1 & Cluster 2 & Cluster 3 & Cluster 4 & Cluster 5 \\
\hline Animal food (in \%) & 66.5 & 68.0 & 56.4 & 66.5 & 73.6 & 66.8 \\
Plant food (in \%) & 33.5 & 32.0 & 43.6 & 33.5 & 26.4 & 33.2 \\
\hline Number of households in cluster (in \%) & 100 & 5.7 & 17.9 & 19.4 & 25.5 & 31.5 \\
Number of people in cluster (in \%) & 100 & 5.0 & 18.3 & 19.7 & 24.7 & 32.3 \\
\hline
\end{tabular}




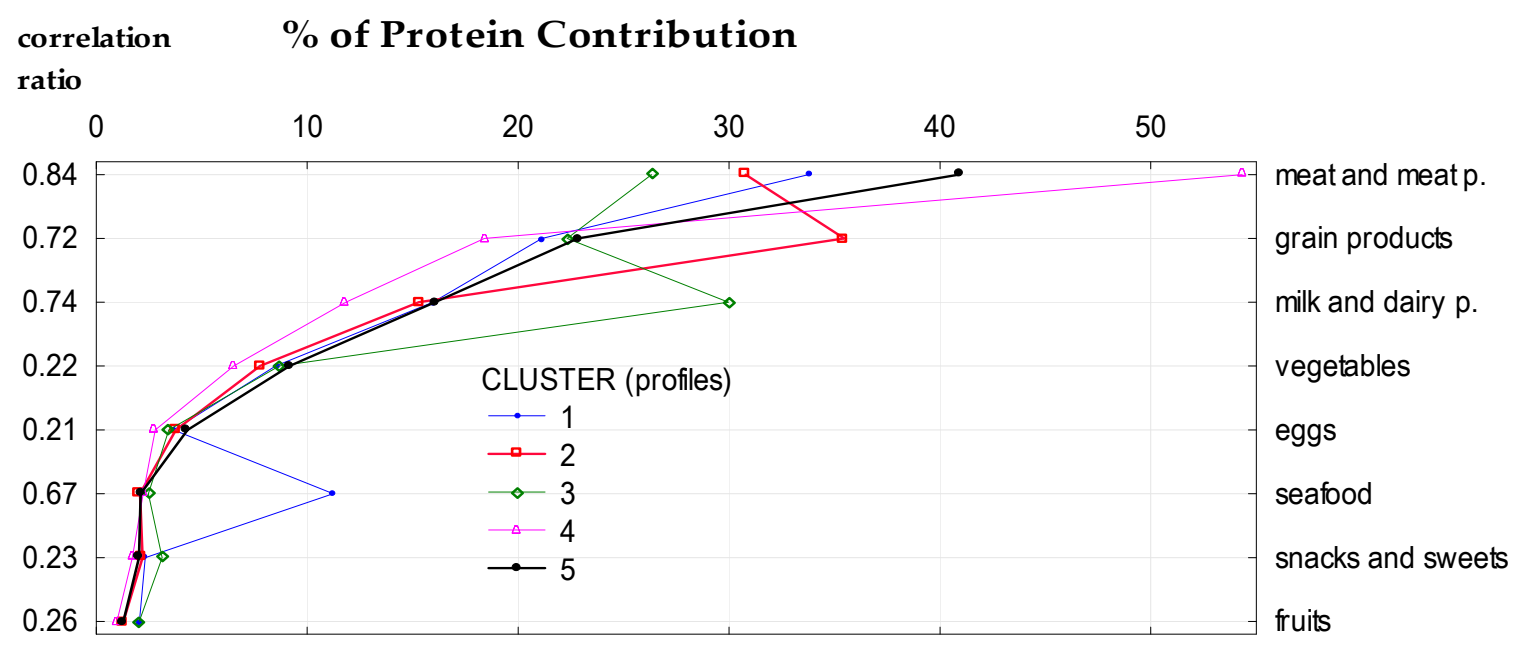

Figure 1. Cluster analysis of population sample in relation to the food categories contribution to total protein supply. p.--products.

\section{Discussion}

This analysis determined the sources of protein and 18 amino acids in the average Polish diet based on the 2016 HBS. It also ranked 13 food and beverage categories and 42 food and beverage groups including 91 food products. The main contributors of protein were meat and meat products $(39.0 \%$ of total protein supply), grain products $(23.9 \%)$, and milk and dairy products $(18.1 \%)$. The combined share of these food categories exceeded $80 \%$ of the total protein supply. In the category of meat and meat products, the largest contributors of protein were meat products (processed red and poultry meat products) $17.4 \%$, red meat (beef, pork, sheep and goat) $9.9 \%$, and poultry (mainly chicken) $9.9 \%$. In the grain product category, the highest ranked food group in protein contribution was bread, rolls and bread products, delivering $16.5 \%$ of total protein supply. In dairy products, three food groups were ranked as important protein sources: cheese (5.6\%), milk (5.4\%), and yogurts and milk drinks $(3.7 \%)$.

Three other studies were selected for comparison of food sources of total protein contribution to the average Polish diet: 2003-2006 NHANES (National Health and Nutrition Examination Survey 2003-2006) [31], 2007-2010 NHANES (National Health and Nutrition Examination Survey 2007-2010) [26], and 2011-2012 NNPAS (Australian National Nutrition and Physical Activity Survey 2011-2012) [32]. The 2003-2006 NHANES research identified the main sources of protein as follows: poultry $(14.4 \%)$, beef $(14 \%)$, pork, ham, bacon $(5.7 \%)$, fish and shellfish $(5.0 \%)$, and frankfurters, sausages, and luncheon meats (4.4\%) [31]. In the average Australian diet, the contribution of meats to protein supply amounted to 49\% (2011-2012 NNPAS). Within the red meat category, beef was the most popular meat type, followed by lamb and pork. In the poultry category, chicken was the major meat type, together with other poultry meats such as duck, turkey [32]. To summarize the comparison of protein sources, meat and meat products contributed $39.0 \%$ of total protein in the average Polish diet, $46.0 \%$ in the American diet and $49.0 \%$ in the Australian diet [26,32]. Milk and dairy products delivered $16 \%$ and $18.1 \%$ of total protein to the American and Polish diets, respectively. The share of milk amounted to $5.5 \%$ and $5.4 \%$ in the American and Polish diet, while cheese was responsible for 4.3 and $5.6 \%$ of total protein supply, respectively [26]. These differences in protein contribution in the Polish, American and Australian diets are related to various dietary patterns determined by consumer preferences, product availabilities and factors determining the food purchasing process.

Our research indicated the impact of 14 socio-demographic and economic factors on the protein intake in the average Polish diet. The largest impact was observed for the following factors: respondent education, degree of urbanization, study month, and usage of agricultural land. We identified five clusters of different animal vs. plant protein ratios and shares of eight food categories in the protein contribution. In the average Polish diet, the share of animal food in total protein supply amounted to $66.5 \%$ in the total population and varied from $56.4 \%$ to $73.6 \%$ among the clusters. In comparison, 
plant food was the source of less protein ( $33.5 \%$ in total population varying from $26.4 \%$ to $43.6 \%$ ). The 2007-2010 NHANES analysis indicated that the share of animal protein equaled $62 \%$, whereas plant protein represented $30 \%$ of total protein intake [26].

There is limited data on the food source of amino acids in diets. Our findings indicated that, in the average Polish diet, BCAAs were delivered by meat and meat products, which contributed $39.8 \%$ of leucine, $41.3 \%$ of isoleucine, and $37.4 \%$ valine. The other main food sources for BCAAs were grain products, and milk and dairy products. The detailed information indicated that processed red and poultry products, and bread, rolls and bread products were the main food group sources in the contribution of BCAAs. These findings should be taken into consideration when considering the quality of vegan, vegetarian and flexitarian diets due to the role of BCAAs in protein synthesis, which is widely described in the scientific literature $[8,10,17,61-63]$. BCAA content is generally higher in animal proteins than plant proteins [8,9], with the highest level in red meat [8].

As far as other EAAs are concerned, in the average Polish diet, meat and meat products were the main food category source of histidine $(46.6 \%)$, lysine $(49.2 \%)$, threonine $(44.7 \%)$, tryptophan $(41.2 \%)$, phenylalanine $(35.3 \%)$, and methionine $(44.2 \%)$. Grain products ranked second in terms of the contribution of other EAAs delivering from $18.4 \%$ (for methionine) to $26.3 \%$ of phenylalanine. The share of milk and dairy products in the intake of other EAAs amounted to $15-20 \%$ of daily intake. It is underlined in the scientific literature that food of animal origin provides important nutrients, including lysine, bioavailable iron and zinc, that are not easily delivered by plant food [64]. There is also discussion in the literature that chicken and turkey are important elements in a balanced diet during growth with specific requirements $[65,66]$.

Considering tryptophan, four food groups delivered more than $50 \%$ of average intake in the Polish diet, including meat products $(18.4 \%)$, bread, rolls, and bread products $(12.9 \%)$, red meat $(10.6 \%)$, and poultry $(10.6 \%)$. This structure of tryptophan contribution to average diets is important due to the role of tryptophan as a precursor of serotonin in food intake and appetite and this is analyzed in the scientific literature [7]. This function of tryptophan is related to carbohydrate-rich, protein-poor meals [67], and eating behavior control, meal size, and body weight [68].

Histidine was delivered to the average Polish diet by meat products $(21.2 \%)$, bread, rolls, and bread products $(13.1 \%)$, red meat $(11.8 \%)$, and poultry (11.6\%). Increasing poultry consumption determined the share of poultry in contributing histidine, which is analyzed in the literature $[65,66]$. For methionine and threonine, the same order of food groups was observed as for histidine. The highest share was noticed in the case of meat products (19.9\% for methionine contribution and $20.6 \%$ in threonine intake). Subsequent places were occupied by bread, rolls and bread products ( $13.7 \%$ and $12.7 \%$, respectively), poultry (11.4\% and $9.8 \%)$, and red meat (11.1\% and $12.3 \%)$. In the case of phenylalanine, in the average Polish diet, bread, rolls and bread products were most important, delivering $18.0 \%$ of total intake. The other food groups functioning as phenylalanine contributors were: meat products $(16.4 \%)$, red meat $(9.2 \%)$, poultry $(7.9 \%)$, and cheese $(6.2 \%)$.

To summarize, it should be stressed that the content of EAAs is analyzed in assessments of diet quality in terms of the capacity of the diet to provide needs for protein synthesis $[9,69]$. This is especially crucial in the assessment of non-meat diets due to increasing interest in vegetarianism and veganism $[10,70-74]$. Health professionals should encourage vegetarians to include a variety of protein-rich foods, such as whole grains; legumes; beans, split peas and baked beans; soy products; nuts and seeds [10].

Our findings indicated that CEAAs and NEAAs were mainly delivered by meat and grain products to the average Polish diet. A share of the contribution of meat and meat products exceeding $40 \%$ was noted for glycine (52.5\%), alanine (48.7\%), arginine (46.1\%), and aspartic acid $(41.7 \%)$. For cysteine, tyrosine, glutamic acid and serine, the level of the contribution of meat and meat products amounted to 30-40\%; a supply below 30\% was identified in the case of proline. Grain products were the main contributors of cysteine, delivering $41.7 \%$ of the total intake of this amino acid, glutamic acid $(33.8 \%)$, and proline (34.1\%). The other CEAAs and NEAAs were delivered by grain products 
at levels of 20-30\% (serine, arginine, and tyrosine) and below 20\% (aspartic acid, alanine). Milk and dairy products were the largest contributors of CEAAs and NEAAs (above 20\%) in the case of proline $(24.8 \%)$, tyrosine $(23.6 \%)$, and serine $(21.1 \%)$. A contribution of this food category at the level of $10-20 \%$ of CEAAs and NEAAs was noted for arginine (11.3\%), alanine (11.9\%), aspartic acid (14.3\%), and glutamic acid (18.9\%). The lowest share of milk and dairy products (below 10\%) was identified for glycine and cysteine.

The 2016 HBS sample range (38,886 households), representative sample selection, consistent approach to classifying food products, use of the HBS methodology to analyze food sources of total protein and 18 amino acids, and animal/plant protein ratios are the strengths of the current study. However, there are some limitations related to the reliance on self-report special budget books, which can under- or overestimate consumption data, even though HBS uses well-established procedures. Additionally, the current edition of 'Nutritive Value Tables for Foods and Meals' (4th ed., 2017) includes new products and technological modifications, which may cause difficulties in comparison of current results with data from earlier years. Therefore, further research is needed to identify food sources of other nutrients, and to assess the impact of socio-demographic, and economic factors on the structure of other nutrient contributions to the average Polish diet.

\section{Conclusions}

This population-based study provides a comprehensive analysis of food sources of total protein and 18 amino acids contributing to the average Polish diet. Our findings indicated that the majority of total protein was delivered by three main food categories: meat and meat products, grain products, and milk and dairy products (with combined share exceeding $80 \%$ of total protein supply). Concerning the contribution of EAAs to the average Polish diet, the share of meat and meat products ranged from $35.3 \%$ for phenylalanine to $49.2 \%$ in the case of lysine. Grain products delivered from $10.1 \%$ (of lysine) to $26.3 \%$ (of phenylalanine) of EAAs, while milk and dairy products contributed $17.0 \%$ (for histidine) to $21.5 \%$ (of lysine) of EAAs. The share of animal food in total protein supply amounted to $66.5 \%$ compared to plant food (33.5\%). These results should be taken into consideration in the quality assessment of non-meat diets due to the increasing popularity of vegetarianism and veganism. Knowledge of sources of protein and amino acids can help dietary professionals to develop strategies with a wide spectrum of food products to meet nutrient recommendations for various consumer groups.

Supplementary Materials: The following Tables are available in http:/ /www.mdpi.com/2072-6643/10/12/1977/s1. Supplemental Section: Table S1. Food group sources of protein contribution to the average Polish diet (food categories and groups contributed at least $0.2 \%$ of protein), Table S2. Food categories and groups sources of leucine contribution to the average Polish diet (food categories and groups contributed at least $0.2 \%$ of leucine), Table S3. Food categories and groups sources of isoleucine contribution to the average Polish diet (food categories and groups contributed at least $0.2 \%$ of isoleucine), Table S4. Food categories and groups sources of valine contribution to the average Polish diet (food categories and groups contributed at least $0.2 \%$ of valine), Table S5. Food categories and groups sources of lysine contribution to the average Polish diet (food categories and groups contributed at least $0.2 \%$ of lysine), Table S6. Food categories and groups sources of histidine contribution to the average Polish diet (food categories and groups contributed at least $0.2 \%$ of histidine), Table S7. Food categories and groups sources of threonine contribution to the average Polish diet (food categories and groups contributed at least $0.2 \%$ of threonine), Table S8. Food categories and groups sources of tryptophan contribution to the average Polish diet (food categories and groups contributed at least $0.2 \%$ of tryptophan), Table S9. Food categories and groups sources of phenylalanine contribution to the average Polish diet (food categories and groups contributed at least $0.2 \%$ of phenylalanine), Table S10. Food categories and groups sources of methionine contribution to the average Polish diet (food categories and groups contributed at least $0.2 \%$ of methionine), Table S11. Food categories and groups sources of cysteine contribution to the average Polish diet (food categories and groups contributed at least $0.2 \%$ of cysteine), Table S12. Food categories and groups sources of tyrosine contribution to the average Polish diet (food categories and groups contributed at least $0.2 \%$ of tyrosine), Table S13. Food categories and groups sources of arginine contribution to the average Polish diet (food categories and groups contributed at least $0.2 \%$ of arginine), Table S14. Food categories and groups sources of glycine contribution to the average Polish diet (food categories and groups contributed at least $0.2 \%$ of glycine), Table S15. Food categories and groups sources of proline contribution to the average Polish diet (food categories and groups contributed at least $0.2 \%$ of proline), Table S16. Food categories and groups sources of aspartic acid contribution to the average Polish diet (food categories and groups contributed at least $0.2 \%$ of aspartic acid), Table S17. Food categories and groups sources of glutamic acid contribution to the average Polish diet (food categories and groups contributed at 
least $0.2 \%$ of glutamic acid), Table S18. Food categories and groups sources of serine contribution to the average Polish diet (food categories and groups contributed at least $0.2 \%$ of serine), Table S19. Food categories and groups sources of alanine contribution to the average Polish diet (food categories and groups contributed at least $0.2 \%$ of alanine).

Author Contributions: H.G.-W. contributed to article design, food grouping, statement of ranking, results discussion; data analysis and description; W.L. conducted calculations from primary data base of 2016 HBS using $\mathrm{R}$ environment, and participated in the exploratory and cluster analysis; O.K. was involved in statement of ranking and data description. A.K.-C. and M.C. were involved in data description. K.R. participated in the exploratory and cluster analysis. All The authors participated in conclusions, read and approved the final manuscript.

Funding: The publication is financed by Polish Ministry of Science and Higher Education within funds of Faculty of Human Nutrition and Consumer Sciences, Warsaw University of Life Sciences (WULS), for scientific research.

Acknowledgments: The authors are grateful to the Central Statistical Office; the analysis was conducted based on the primary 2016 HBS.

Conflicts of Interest: The authors declare no conflict of interest.

\section{References}

1. Wolfe, R.R.; Baum, J.I.; Starck, C.; Moughan, P.J. Factors contributing to the selection of dietary protein food sources. Clin. Nutr. 2018, 37, 130-138. [CrossRef]

2. Ten Haaf, D.; van Dongen, E.; Nuijten, M.; Eijsvogels, T.; de Groot, L.; Hopman, M. Protein Intake and Distribution in Relation to Physical Functioning and Quality of Life in Community-Dwelling Elderly People: Acknowledging the Role of Physical Activity. Nutrients 2018, 10, 506. [CrossRef]

3. Uauy, R.; Kurpad, A.; Tano-Debrah, K.; Otoo, G.E.; Aaron, G.A.; Toride, Y.; Ghosh, S. Role of Protein and Amino Acids in Infant and Young Child Nutrition: Protein and Amino Acid Needs and Relationship with Child Growth. J. Nutr. Sci. Vitaminol. (Tokyo) 2015, 61, S192-S194. [CrossRef]

4. Lonnie, M.; Hooker, E.; Brunstrom, J.M.; Corfe, B.M.; Green, M.A.; Watson, A.W.; Williams, E.A.; Stevenson, E.J.; Penson, S.; Johnstone, A.M. Protein for Life: Review of Optimal Protein Intake, Sustainable Dietary Sources and the Effect on Appetite in Ageing Adults. Nutrients 2018, 10. [CrossRef]

5. Ozdemir, A. Macronutrients in Adolescence. Int. J. Caring Sci. 2016, 9, 1162-1166.

6. Wu, G.; Fanzo, J.; Miller, D.D.; Pingali, P.; Post, M.; Steiner, J.L.; Thalacker-Mercer, A.E. Production and supply of high-quality food protein for human consumption: Sustainability, challenges, and innovations. Ann. N. Y. Acad. Sci. 2014, 1321, 1-19. [CrossRef] [PubMed]

7. Greco, E.; Winquist, A.; Jacob Lee, T.; Collins, S.; Lebovic, Z.; Zerbe-Kessinger, T.; Jahan Mihan, A. The Role of Source of Protein in Regulation of Food Intake, Satiety, Body Weight and Body Composition. J. Nutr. Health Food Eng. 2017, 6. [CrossRef]

8. Wyness, L. The role of red meat in the diet: Nutrition and health benefits. Proc. Nutr. Soc. 2016, 75, $227-232$. [CrossRef]

9. Millward, D.J.; Layman, D.K.; Tomé, D.; Schaafsma, G. Protein quality assessment: impact of expanding understanding of protein and amino acid needs for optimal health. Am. J. Clin. Nutr. 2008, 87, 1576-1581. [CrossRef]

10. Baines, S.K. Protein and vegetarian diets. Med. J. Aust. 2013, 199, S7-S10. [CrossRef]

11. Layman, D.K. Dietary Guidelines should reflect new understandings about adult protein needs. Nutr. Metab. (Lond.) 2009, 6, 12. [CrossRef]

12. Wolfe, R.R. Branched-chain amino acids and muscle protein synthesis in humans: myth or reality? J. Int. Soc. Sports Nutr. 2017, 14, 30. [CrossRef]

13. Young, V.R.; Borgonha, S. Criteria and Significance of Dietary Protein Sources in Humans Nitrogen and Amino Acid Requirements: The Massachusetts Institute of Technology Amino Acid Requirement Pattern 1,2. J. Nutr. 2000, 130, 1841-1849. [CrossRef] [PubMed]

14. Tijhuis, M.J. Replacement of Meat and Dairy by More Sustainable Protein Sources in the Netherlands Quality of the Diet; National Institute for Public Health and the Environment, Ministry of Health, Welfare and Sport: Bilthoven, Denmark, 2011.

15. Blomstrand, E.; Eliasson, J.; Karlsson, H.K.R.; Köhnke, R. Branched-Chain Amino Acids Activate Key Enzymes in Protein Synthesis after Physical Exercise. J. Nutr. 2006, 136, 269S-273S. [CrossRef] [PubMed] 
16. Paddon-Jones, D.; Rasmussen, B.B. Dietary protein recommendations and the prevention of sarcopenia. Curr. Opin. Clin. Nutr. Metab. Care 2009, 12, 86-90. [CrossRef] [PubMed]

17. Garlick, P. The role of leucine in the regulation of protein metabolism. J. Nutr. 2005, 135, 1553S-1556S. [CrossRef]

18. Volpi, E.; Kobayashi, H.; Sheffield-Moore, M.; Mittendorfer, B.; Wolfe, R.R. Essential amino acids are primarily responsible for the amino acid stimulation of muscle protein anabolism in healthy elderly adults. Am. J. Clin. Nutr. 2003, 78, 250-258. [CrossRef]

19. Kobayashi, H.; Kato, H.; Hirabayashi, Y.; Murakami, H.; Suzuki, H. Modulations of Muscle Protein Metabolism by Branched-Chain Amino Acids in Normal and Muscle-Atrophying Rats. J. Nutr. 2006, 136, 234S-236S. [CrossRef]

20. Volpi, E.; Mittendorfer, B.; Rasmussen, B.; Wolfe, R. The response of muscle protein anabolism to combined hyperaminoacidemia and glucose-induced hyperinsulinemia is impaired in the elderly. J. Clin. Endocrinol. Metab. 2000, 85, 4481-4490. [CrossRef]

21. Paddon-Jones, D.; Westman, E.; Mattes, R.D.; Wolfe, R.R.; Astrup, A.; Westerterp-Plantenga, M. Protein, weight management, and satiety. Am. J. Clin. Nutr. 2008, 87, 1558S-1561S. [CrossRef]

22. Hoffman, J.R.; Falvo, M.J. Protein-Which is best? J. Sport Sci. Med. 2004, 3, 118-130.

23. Tomé, D. Digestibility Issues of Vegetable versus Animal Proteins: Protein and Amino Acid Requirements-Functional Aspects. Food Nutr. Bull. 2013, 34, 272-274. [CrossRef] [PubMed]

24. Gilani, G.S. Background on international activities on protein quality assessment of foods. Br. J. Nutr. 2012, 108, S168-S182. [CrossRef] [PubMed]

25. Millward, D.J. Meat or wheat for the next millennium? Plenary Lecture The nutritional value of plant-based diets in relation to human amino acid and protein requirements. Proc. Nutr. Soc. 2016, 58, 249-260. [CrossRef]

26. Pasiakos, S.M.; Agarwal, S.; Lieberman, H.R.; Fulgoni, V.L. Sources and amounts of animal, dairy, and plant protein intake of US adults in 2007-2010. Nutrients 2015, 7, 7058-7069. [CrossRef]

27. Phillips, S.M.; Iii, V.L.F.; Heaney, R.P.; Nicklas, T.A.; Slavin, J.L.; Weaver, C.M. Commonly consumed protein foods contribute to nutrient intake, diet quality, and nutrient adequacy. Am. J. Clin. Nutr. 2015, 101, 1346-1352. [CrossRef] [PubMed]

28. Wirfält, E.; Drake, I.; Wallström, P. What do review papers conclude about food and dietary patterns? Food Nutr. Res. 2013, 57, 20523. [CrossRef] [PubMed]

29. Lim, K.H.C.; Riddell, L.J.; Nowson, C.A.; Booth, A.O.; Szymlek-Gay, E.A. Iron and zinc nutrition in the economically-developed world: A review. Nutrients 2013, 5, 3184-3211. [CrossRef]

30. Clarys, P.; Deliens, T.; Huybrechts, I.; Deriemaeker, P.; Vanaelst, B.; De Keyzer, W.; Hebbelinck, M.; Mullie, P. Comparison of Nutritional Quality of the Vegan, Vegetarian, Semi-Vegetarian, Pesco-Vegetarian and Omnivorous Diet. Nutrients 2014, 6, 1318-1332. [CrossRef]

31. O'Neil, C.E.; Keast, D.R.; Fulgoni, V.L.; Nicklas, T.A. Food sources of energy and nutrients among adults in the US: NHANES 2003-2006. Nutrients 2012, 4, 2097-2120. [CrossRef]

32. Sui, Z.; Raubenheimer, D.; Rangan, A. Consumption patterns of meat, poultry, and fish after disaggregation of mixed dishes: secondary analysis of the Australian National Nutrition and Physical Activity Survey 2011-12. BMC Nutr. 2017, 3, 52. [CrossRef]

33. De Gavelle, E.; Huneau, J.F.; Mariotti, F. Patterns of protein food intake are associated with nutrient adequacy in the general french adult population. Nutrients 2018, 10. [CrossRef]

34. Henchion, M.; Hayes, M.; Mullen, A.; Fenelon, M.; Tiwari, B. Future Protein Supply and Demand: Strategies and Factors Influencing a Sustainable Equilibrium. Foods 2017, 6, 53. [CrossRef] [PubMed]

35. Household Budget Survey in 2016; Central Statistical Office: Warsaw, Poland, 2017.

36. Methodology of Household Survey (in Polish); Barlik, M.; Krystyna, S. (Eds.) Central Statistical Office, Zakład Wydawnictw Statystycznych: Warsaw, Poland, 2011.

37. Laskowski, W.; Górska-Warsewicz, H.; Kulykovets, O. Meat, Meat Products and Seafood as Sources of Energy and Nutrients in the Average Polish Diet. Nutrients 2018, 10, 1412. [CrossRef] [PubMed]

38. Laskowski, W.; Górska-Warsewicz, H. Nutrient Density of the Average Polish Diet. Economic Analysis (in Polish), 1st ed.; Laskowski Publisher: Warsaw, Poland, 2014; ISBN 978-83-941257-1-4.

39. What We Eat in America. Available online: https://www.ars.usda.gov/ARSUserFiles/80400530/pdf/1314/ Food_categories_2013-2014.pdf (accessed on 13 August 2018). 
40. Part E. Section 2: Supplementary Documentation to the 2015 DGAC Report Scientific Report of the 2015 Dietary Guidelines Advisory Committee Appendix E-2.7: Major Categories and Subcategories used in DGAC Analyses of WWEIA Food Categories. Available online: https:/ /health.gov/dietaryguidelines/DGACMajor-categories-and-subcategories-from-WWEIA-FoodCategories.pdf (accessed on 13 August 2018).

41. Rhodes, D.G.; Adler, M.E.; Clemens, J.C. What we eat in America food categories and changes between survey cycles. J. Food Compos. Anal. 2017, 64, 107-111. [CrossRef]

42. Kunachowicz, H.; Przygoda, B.; Nadolna, I.; Iwanow, K. Tabele składu i wartości odżywczej żywności, 4th ed.; PZWL Wydawnictwo Lekarskie: Warsaw, Poland, 2017; ISBN 9788320053111.

43. Fox, J.; Leanage, A. R and the Journal of Statistical Software. J. Stat. Softw. 2016, 73, 1-13. [CrossRef]

44. R Development Core Team R Language Definition. Web 2011, 62. [CrossRef]

45. Lang, M. Efficient $R$ Programming. J. Stat. Softw. 2017, 80. [CrossRef]

46. Rejman, K.; Kowrygo, B.; Laskowski, W. Evaluation of the Structure of Food Consumption in Poland in the Context of Demands of Sustainable Consumption (in Polish). J. Agribus. Rural Dev. 2015, 37, 503-512.

47. Reimann, C.; Wiley InterScience (Online service). Statistical Data Analysis Explained: Applied Environmental Statistics with R; John Wiley \& Sons: Chichester, UK, 2008; ISBN 9780470987605.

48. Venables, W.N.; Smith, D.M. An \{Introduction $\}$ to $\{R\}, 2$ 2nd ed.; Network Theory Limited: London, UK, 2009; ISBN 0-9546120-8-6.

49. Wesley, S.; LeHew, M.; Woodside, A.G. Consumer decision-making styles and mall shopping behavior: Building theory using exploratory data analysis and the comparative method. J. Bus. Res. 2006, 59, 535-548. [CrossRef]

50. Behrens, J.T. Principles and procedures of exploratory data analysis. Psychol. Methods 1997, 2, $131-160$. [CrossRef]

51. Dubes, R.; Jain, A.K. Clustering Methodologies in Exploratory Data Analysis. Adv. Comput. 1980, 19, 113-228. [CrossRef]

52. Al-Omary, A.Y.; Jamil, M.S. A new approach of clustering based machine-learning algorithm. Knowl.-Based Syst. 2006, 19, 248-258. [CrossRef]

53. Zhao, Y.; Karypis, G. Empirical and Theoretical Comparisons of Selected Criterion Functions for Document Clustering. Mach. Learn. 2004, 55, 311-331. [CrossRef]

54. Xu, R.; WunschII, D. Survey of Clustering Algorithms. IEEE Trans. Neural Netw. 2005, 16, 645-678. [CrossRef] [PubMed]

55. Parsons, L.; Haque, E.; Liu, H. Subspace clustering for high dimensional data. ACM SIGKDD Explor. Newsl. 2004, 6, 90-105. [CrossRef]

56. Wilks, D.S. Cluster Analysis. Int. Geophys. 2011, 100, 603-616. [CrossRef]

57. Aliguliyev, R.M. Clustering of document collection-A weighting approach. Expert Syst. Appl. 2009, 36, 7904-7916. [CrossRef]

58. Tan, M.P.; Broach, J.R.; Floudas, C.A. A novel clustering approach and prediction of optimal number of clusters: global optimum search with enhanced positioning. J. Glob. Optim. 2007, 39, 323-346. [CrossRef]

59. Schikuta, E.; Fritz, F. An Execution Framework for Grid-clustering Methods. Procedia Comput. Sci. 2016, 80, 2322-2326. [CrossRef]

60. Rojas, R. 15 Kohonen Networks 15.1. In Neural Networks; Springer: Berlin, Germany, 1996; pp. 391-412, ISBN 9783540605058.

61. Zhang, Y.; Guo, K.; LeBlanc, R.E.; Loh, D.; Schwartz, G.J.; Yu, Y.-H. Increasing Dietary Leucine Intake Reduces Diet-Induced Obesity and Improves Glucose and Cholesterol Metabolism in Mice via Multimechanisms. Diabetes 2007, 56, 1647-1654. [CrossRef] [PubMed]

62. Layman, D. The role of leucine in weight loss diets and glucose homeostasis. J. Nutr. 2003, 133, 261S-267S. [CrossRef] [PubMed]

63. Jang, B.; Rhee, Y.; Hee, J. Business cycle and credit risk modeling with jump risks. J. Empir. Financ. 2016, 39, 15-36. [CrossRef]

64. Walker, P.; Rhubart-Berg, P.; Mckenzie, S.; Kelling, K.; Lawrence, R.S. Public health implications of meat production and consumption. Public Health Nutr. 2005, 8, 348-356. [CrossRef] [PubMed]

65. Marangoni, F.; Corsello, G.; Cricelli, C.; Ferrara, N.; Ghiselli, A.; Lucchin, L.; Poli, A. Role of poultry meat in a balanced diet aimed at maintaining health and wellbeing: An Italian consensus document. Food Nutr. Res. 2015, 59, 1-11. [CrossRef] [PubMed] 
66. Rand, W.M.; Young, V.R. Statistical Analysis of Nitrogen Balance Data with Reference to the Lysine Requirement in Adults. J. Nutr. 1999, 129, 1920-1926. [CrossRef] [PubMed]

67. Wurtman, R.J.; Wurtman, J.J. Do carbohydrates affect food intake via neurotransmitter activity? Appetite 1988, 11 (Suppl. 1), 42-47. [CrossRef]

68. Leibowitz, S.F.; Alexander, J.T. Hypothalamic serotonin in control of eating behavior, meal size, and body weight. Biol. Psychiatry 1998, 44, 851-864. [CrossRef]

69. Cobiac, L.; Nestel, P.J.; Wing, L.M.H.; Howe, P.R.C. A low-sodium diet supplemented with fish oil lowers blood pressure in the elderly. J. Hypertens. 1992, 10, 87-92. [CrossRef]

70. Pilis, W.; Stec, K.; Zych, M.; Pilis, A. Health benefits and risk associated with adopting a vegetarian diet. Rocz. Państwowego Zakładu Hig. 2014, 65, 9-14.

71. Hunt, J.R. Biaoavailability of iron, zinc, and other trace minerals from vegetarian diets. Am. J. Clin. Nutr. 2003, 78, 633S-639S. [CrossRef] [PubMed]

72. Position of the American Dietetic Association: Vegetarian Diets. J. Am. Diet. Assoc. 2009, 109, $1266-1282$. [CrossRef]

73. Key, T.J.; Appleby, P.N.; Rosell, M.S. Health effects of vegetarian and vegan diets. Proc. Nutr. Soc. 2006, 65, 35-41. [CrossRef] [PubMed]

74. Young, V.R.; Pellett, P.L. Plant proteins in relation to human and amino acid nutrition. Am. J. Clin. Nutr. 1994, 59, 1203S-1212S. [CrossRef] [PubMed]

(C) 2018 by the authors. Licensee MDPI, Basel, Switzerland. This article is an open access article distributed under the terms and conditions of the Creative Commons Attribution (CC BY) license (http:/ / creativecommons.org/licenses/by/4.0/). 